\title{
Trigeminal Neuralgia Caused by Pontocerebellar Angle Epidermoid Tumor: A Case Report and Review of Literature
}

\author{
Pontoserebellar Köşe Epidermoid Tümörünün Neden Olduğu Trigeminal Nevralji: Olgu \\ Sunumu ve Literatürün Gözden Geçirilmesi
}

\author{
Muhammet Bahadır Yilmaz ${ }^{1}$, Semra Yilmaz ${ }^{2}$, Ayhan Tekiner ${ }^{1}$ \\ ${ }^{1}$ Kayseri Training and Research Hospital, Clinic of Brain Nerve Surgery, Kayseri, Turkey \\ 2Kayseri Training and Research Hospital, Clinic of Nourology, Kayseri, Turkey
}

\section{Summary}

Trigeminal neuralgia (TN) is the most commonly seen craniofacial pain syndrome. Etiology of TN can be divided into classical (idiopathic and vascular compression) and symptomatic (tumor, demyelinating, and ischemic) types. Especially, symptomatic trigeminal neuralgia is seen with tumors located in the cerebellopontine angle. Epidermoid tumors comprise about $1 \%$ of all brain tumors and 5\% of tumors located in the cerebellopontine angle. These tumors may present with trigeminal neuralgia due to localization. In this article, we present case with trigeminal neuralgia due to pontocerebellar angle epidermoid tumor, as well as examine to approach for symptomatic trigeminal neuralgia, due to epidermoid tumors. (Turkish Journal of Neurology 2015; 21:31-3)

Key Words: Trigeminal neuralgia, epidermoid tumor, pontocerebellar angle, treatment

Conflicts of Interest: The authors reported no conflict of interest related to this article.

\section{Özet}

Trigeminal nevralji (TN) en sık görülen kraniofasiyal ağrı sendromudur. TN etiyolojisi klasik (idiyopatik ve vasküler bası) ve semptomatik (tümör, demyelinizan ve iskemik) olarak ikiye ayrılır. Semptomatik olanlar özellikle pontoserebellar köşe yerleşimli tümörlerde görülür. Epidermoid tümörler tüm beyin tümörlerinin yaklaşık \%1'ini ve pontoserebellar köşede yerleşen tümörlerin \%5'ini oluşturur. Bu tümörler lokalizasyonu nedeniyle trigeminal nevralji ile karşımıza çıkabilir. Biz bu yazımızda epidermoid tümör kaynaklı trigeminal nevraljili olguyu sunuyoruz ve epidermoid tümör nedeniyle gelişen semptomatik trigeminal nevraljiye yaklaşımı inceliyoruz. (Türk Nöroloji Dergisi 2015; 21:31-3)

Anahtar Kelimeler: Trigeminal nevralji, epidermoid tümör, pontoserebellar köşe, tedavi

Çıkar Çatışması: Yazarlar bu makale ile ilgili olarak herhangi bir çıkar çatışması bildirmemiştir.

\section{Introduction}

Trigeminal neuralgia (TN) is the most common craniofacial pain syndrome. It often occurs as an shock type paroxysmal pain on one side of the face and it can be triggered by external stimuli as well. It is more common in women. Trigeminal neuralgia (TN) is classified as either classical and symptomatic (1). Classical TN diagnosis is used for idiopathic and vascular pressure-related cases whereas symptomatic TN is used for TN due to structural abnormalities. Structural causes include the tumors located in posterior fossa, brainstem infarcts and multiple sclerosis plaques located in the brainstem (2). Therefore, following the clinically motivated TN diagnosis, possible causes of nerve compression must be investigated using radiological methods.

Epidermoid tumors constitute $0.2-1.4 \%$ of all intracranial tumors and $5 \%$ of all tumors located in the pontocerebellar corner, 
and they are the $3^{\text {rd }}$ most commonly seen tumors in that area (3). Trigeminal neuralgia cases due to epidermoid tumors have been reported in the literature, even though the reports have been rare. In this article, we present a patient who developed TN due to epidermoid tumor and the possible treatment options.

\section{Case}

Seventy-year-old male patient came to our outpatient clinic with pain affecting the left side of the face for the past 2 months. The patient had severe, transient pain especially triggered during eating and shaving. He had a history of surgery for traumatic left frontotemporal epidural hematoma. His neurological examination showed hypoaesthesia on all 3 branches of the left trigeminal nerve. Other cranial nerves were normal. There were no lateralized motor or sensory deficits. Cranial magnetic resonance imaging (MRI) was performed on the patient due to his present hypoaesthesia. In this cranial MRI, a lesion due to epidermoid tumor, reaching from the left cerebellopontine corner to prepontin cistern, left parahippocampal gyrus and parahippocampal area. The lesion was surrounding the basilar artery, causing constriction. It was isointense with cerebro-spinal fluid (CSF) in T1 and T2A images and congruent with diffusion restriction in the diffusion-weighted
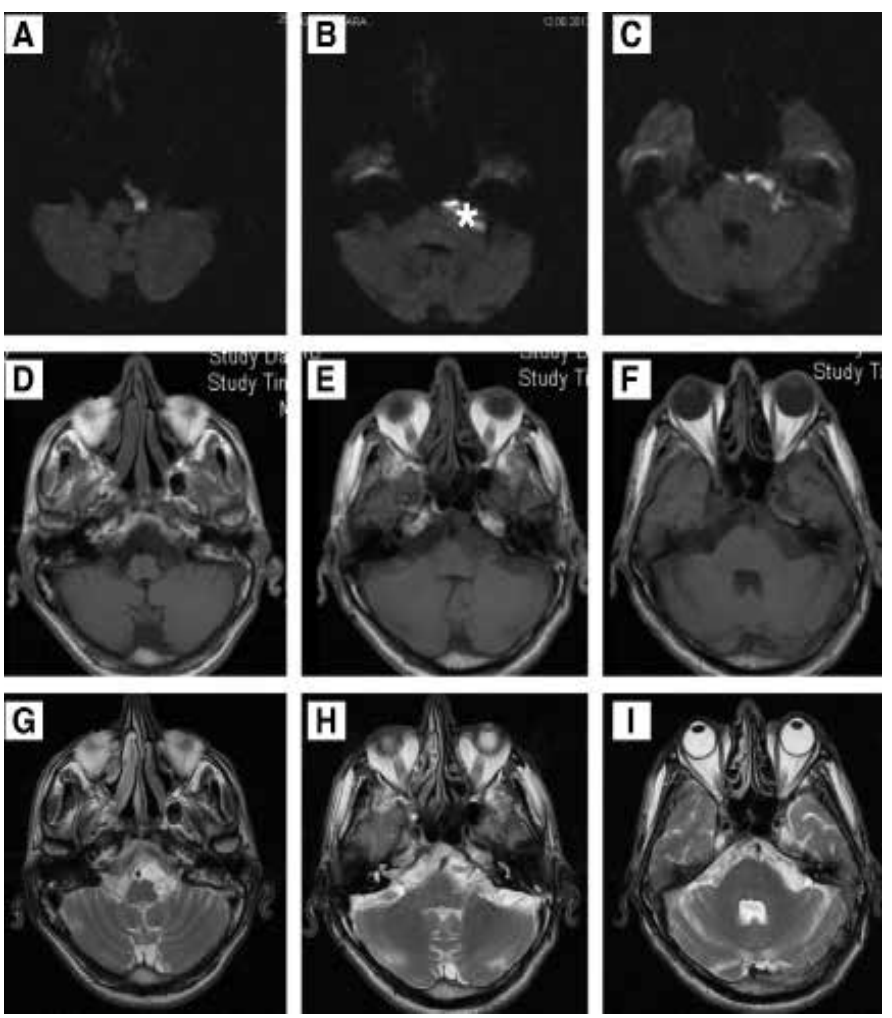

Figure 1. A lesion due to epidermoid tumor, reaching from the left cerebellopontine corner to prepontin cistern, left parahippocampal gyrus and parahippocampal area. The lesion surrounds the basilar artery, causing constriction. It looks isointense with cerebro-spinal fluid in T1 (D, E, F) and T2A (G, H, I) images and congruent with diffusion restriction (star) in the diffusion-weighted images $(\mathrm{A}, \mathrm{B}, \mathrm{C})$. The lesion is in close proximity with Meckel's cave images. It was seen to be in close proximity to Meckel's cave that the left trigeminal nerve goes through and was applying pressure on the trigeminal nerve at that level (Figure 1). Due to the existing pathology, the patient was first recommended for surgery. Patient and relatives refused surgery and carbamazepine $200 \mathrm{~ms} /$ day treatment was started. The dosage was increased gradually until the symptoms were under control, and the patient was scheduled for a $6^{\text {th }}$ month follow-up for MRI.

\section{Discussion}

Classical TN definition involves idiopathic and vascular compression. In classical TN, usually superior cerebellar artery applies pressure on the trigeminal root entry zone. Persistent trigeminal artery and dolichoectatic basilar artery may also cause the compression. Symptomatic TN diagnosis is used for the cases due to structural abnormalities. Tumors, brainstem infarcts, multiple sclerosis have been reported among these (2). Sensory deficits related to trigeminal nerve and bilateral complaints are indicative of these structural abnormalities $(2,4)$. Abnormal trigeminal reflex has high sensitivity and specificity for symptomatic TN. Trigeminal neuralgia cases associated with epidermoid tumors are seen in younger age groups, and the symptoms are longer lasting with continuous pain $(2,3)$. In the cases where the symptoms emerge in the older ages, making this distinction clinically is not easy (3).

Intracranial tumors are rarely seen with symptomatic TN $(<0.8)$ $(2,5)$. While these tumors are often located in posterior fossa like vestibular schwannoma, epidermoid tumor and meningioma, it is reported that middle fossa tumors like meningioma, schwannoma and hypophyseal adenoma may also cause these (2).

Epidermoid tumors located in the pontocerebellar corner have also been reported at $0.2-5.5 \%$ rate in TN patients $(2,3,6)$. Trigeminal neuralgia incidence in patients with epidermoid tumor has been reported in rates ranging from $0 \%$ to $90.6 \%$ (3). Intracranial epidermoid tumors are of neuroectodermal origin, histologically benign and have very slow growth speeds (3). Intracranially, they are most frequently located on pontocerebellar corner, supracerebellar and $3^{\text {rd }}$ ventricle area $(2,7)$. There are studies reporting 8th nerve dysfunction is the most common condition in pontocerebellar corner epidermoid tumors, followed by $\mathrm{TN}(2,3,6)$. In addition, glossopharyngeal neuralgia may cause, hemifacial spasm, cerebellar and brainstem compression (3). According to the MRI studies, T1 findings are often hypointense whereas T2 findings are often hyperintense. Contrast holding is not seen (3). It is important to look at FLAIR and CISS sequences to distinguish them from arachnoid cysts. Son et al. reported that especially CISS sequence is an important tool in detecting epidermoid tumor (3).

The biggest patient series on this topic is the 24-patient study by Meng et al. in $2005(7,8)$. In this study, it was reported that TN may be the first symptom of pontocerebellar corner epidermoid tumor, especially in teenagers (8). In the 25-patient pontocerebellar corner epidermoid tumor series by Mohanty et al., 13 patients had TN, among which 7 did not have any other symptom besides TN, and all of them benefited from surgery (9). Son et al., compared 10 patients who developed TN due to epidermoid tumor with 61 patients who had classical TN due to vascular compression and who 
had undergone microvascular decompression (3). This comparison statistically showed that cases with tumor had an earlier age of symptom onset and surgery age (3). Therefore, pontocerebellar corner and Meckel's cave should be carefully examined especially in young patients with TN (3).

Total excision is important both for TN and epidermoid tumor treatment. The important neural and vascular structures in the region, however, make it difficult. Cranial nerve dysfunction and aseptic meningitis are the most frequent complications of surgery (8). Leaving the capsule may cause recurrence but it would take a long time for these tumors since they grow very slowly. For that reason, some researchers recommend a less aggressive approach when the capsule is adjacent to brainstem and cranial nerves $(3,9)$. On the contrary, Gio et al. reported that the removal of the capsule that is stuck to the nerve is crucial in relieving the pain even though it may also cause nerve damage (10). In the epidermoid tumor cases that cause TN, it is recommended that the vascular compression in the root entry zone must be checked after the total excision, and that microvascular decompression must be performed if there is compression $(7,8)$.

Epidermoid tumors are not responsive to radiotherapy and chemotherapy. Therefore they are not recommended for patients who refuse surgery. It is reported that adjuvant radiotherapy can be used in recurrent and malignant transformation cases (2).

In conclusion, trigeminal nerve sensory deficits, bilateral complaints, abnormal trigeminal reflex, young age and continuous pain should bring symptomatic TN to ming. Comprehensive radiological examination of posterior fossa must be performed.

\section{References}

1. Shulev Y, Trashin A, Gordienko K. Secondary trigeminal neuralgia in cerebellopontine angle tumors. Skull Base 2011;21:287-294.

2. Hung LC, Wu CS, Lin CC, Fang WK, Hsu YC. Epidermoid cyst presenting as isolated trigeminal neuralgia - two case reports. Acta Neurol Taiwan 2013;22:133-137.

3. Son DW, Choi $\mathrm{CH}$, Cha SH. Epidermoid tumors in the cerebellopontine angle presenting with trigeminal neuralgia. J Korean Neurosurg Soc 2010;47:271277.

4. Gronseth G, Cruccu G, Alksne J, Argoff C, Brainin M, Burchiel K, Nurmikko T, Zakrzewska JM. Practice parameter: the diagnostic evaluation and treatment of trigeminal neuralgia (an evidence-based review): report of the Quality Standards Subcommittee of the American Academy of Neurology and the European Federation of Neurological Societies. Neurology 2008;71:11831190.

5. Cirak B, Kiymaz N, Arslanoglu A. Trigeminal neuralgia caused by intracranial epidermoid tumor: report of a case and review of the different therapeutic modalities. Pain Physician 2004;7:129-132.

6. Kobata H, Kondo A, Iwasaki K. Cerebellopontine angle epidermoids presenting with cranial nerve hyperactive dysfunction: pathogenesis and longterm surgical results in 30 patients. Neurosurgery 2002;50:276-285.

7. Roka YB, Bista P, Sharma GR, Sultania PK. Cerebellopontine epidermoid presenting with trigeminal neuralgia for 10 years: a case report. Cases J 2009;2:9345.

8. Meng L, Yuguang L, Feng L, Wandong S, Shugan Z, Chengyuan W. Cerebellopontine angle epidermoids presenting with trigeminal neuralgia. J Clin Neurosci 2005;12:784-786.

9. Mohanty A, Venkatrama SK, Rao BR, Chandramouli BA, JayakumarPN, Das BS. Experience with cerebellopontine angle epidermoids. Neurosurgery 1997;40:24-29.

10. Guo Z, Ouyang H, Cheng Z. Surgical treatment of parapontine epidermoid cysts presenting with trigeminal neuralgia. J Clin Neurosci 2011;18:344-346. 